\title{
岸壁に作用する地震時土王の計算
}

\section{CALCULATION OF SEISMIC EARTH PRESSURE ACTING ON QUAY WALL}

\author{
大原資生*・松田 \\ 博** \\ By Sukeo ÖHARA and Hiroshi MATSUDA
}

\begin{abstract}
Mononobe-Okabe's equation has been proposed in 1924 and has been used for the aseismic design of the retaining wall, today. But it is well known that the effect of cohesion is not considered in this equation.

Author measured a resultant force and a distribution of seismic earth pressure acted on a movable model wall, using a shaking table test. Sand used in the tests is slightly cohesive. The test results were discussed by the comparison with the theoretical results proposed by S. ÖHARA in 1960.

Also, we try to verify the base sliding of the gravity type quay walls which were occured during the earthquakes by our theoretical results.
\end{abstract}

\section{1. 緒言}

岸壁なよ゙，搉壁に作用する地震時土圧の計算には，現 在，物部・岡部の式が用いられている．これは 1924 年 に提案されたものであり, 震度法を応用して導かれた地 震時の主働土圧および受働土圧の計算式であるが，これ には，粘着力までは考慮されていないことは衆知のこと である゙. そのために, 最近粘着力を考虑した 2,3 の 計算式(L),3)発表されているが，その実用に対する評価 はまだできていない。

地震時土圧の評価は，粘着力のない乾燥砂の場合につ いても長年月を要し，まだそのすべてが明らかでないこ とから，粘性土の場合にも，その解明には今後, 多くの 研究結果の蓄積が必要と考えられる.

著者の一-人は以前から地震時土圧についての実験的研 究を行うとともに，裏込土を弾性体とみなしての理論計 算結果を発表 ${ }^{41.5)}$ した. 最近, 粘着力をもつ土の地震時 土王の実験を行い, その結果の考察を行った。 その際に, 先の理論計算結果を用いると, 粘着力のあるときの地震 時土圧も非常によく説明できることがわかった.

* 正会員 工博 山口大学教授 工学部土木工学科 （开755 宇部市常盤台 2557)

** 正会員 工博 山口大学助教授 工学部建設工学科(同上)
地震時土圧の実験では，通常，振動台の上に所要の大 きさの砂槽をのせ，その中に砂を詰めて，所定の加速度 の水平振動を加え，振動方向に直角な側壁に作用する土 圧を測定するという方法がとられる．その際の土圧測定 には,土圧計によって土圧分布を求める方法と,壁をロー ドセルで支え壁全体に加わる土圧合力を求める方法とが ある。

われわれの先の実験(5) 8)では，主として土圧計による 測定が行われた．粘着力のある土を，その単位重量をて きるだけ均一にして砂槽に詰めるには，砂をある程度締 め固めながら，詰めなければならない，そのために，土 圧計が受圧面近くの締め固めの影響を直接受け，土圧測 定值にかなりのばらつきが生じることが多かった。そこ で今回の実験では壁全体に加わる土圧合力を測定するよ うにして，土圧計による測定の不備を補った。

すなわち，側壁は，その下端がヒンジとなっていて， わずかに回転するが，左右のヒンジは上下，水平方向と もロードセルで支えられ，また，壁の上端も水平方向に ロードセルで支えられている。

実験では, 地震時土圧と壁の変位（裏込土のひずみレ ベル）の関係を明らかにし，地震時主働土圧を求めるた めに, 振動中に側壁の上支点を $2.0 \mathrm{~mm}$ だけ外側および 内側に繰り返し変位させて，土圧変化を調べた。 
実験結果の検討には，オシログラフの記録から読み 取った壁の変位と土圧計の測定値, 各ロードセルの出力 との関係を蕧歴曲線として示し, これらの曲線から, 地 震時主働土圧の合力および分布, 土圧合力の作用高, 壁 面摩擦角などについての特性を考察した。

そして,これらの実験結果, 乾燥砂の結果はもちろん， 粘着力のある場合の実験結果が, 前述の理論計算值 ${ }^{4), 5 !}$ によって適切に説明できることがわかった. 本報告では, まずその点について述べ，改めて，先の理論計算值を既 往の被災岸壁に適用した結果についても述べ，本計算結 果の位置付けを明らかにした。

\section{2. 試料および実験装置}

粘着力のある試料は，前回 ${ }^{8}$ 同様に豊浦標準砂にグリ セリンを質量比（砂：グリセリン） $10 ： 1$ の割合で混合 した砂（これを以後グリセリン砂という）を用いた。

グリセリンを混合した砂を用いたのは，実験に使用し た砂槽の深さが $50 \mathrm{~cm}$ であるので，粘着力が大きく， それによる限界深さが $50 \mathrm{~cm}$ 以上となる試料を用いる ことは実験結果の一般性が乏しくなる。そこでわずかの 粘着力をもった試料を作るために，グリセリンを混合し た砂を用いた。

このようにして作られたグリセリン砂の強度定数は三 軸試験によって求められた. Fig. 1, Table 1 にその結 果を示す．供試体の単位重量は砂槽に詰められた状態の それに等しくし，側圧も砂槽の深さが $50 \mathrm{~cm}$ であるこ とを考えて 2.5 10.0 kPa として試験が行われた.

求められたグリセリン砂の粘着力は $1.18 \mathrm{kPa}$ とな り,この值から求められる限界深さは約 $17 \mathrm{~cm}$ である.

なお, 実験結果の比較・検討のため, 気乾状態の豊浦 砂（以後乾燥砂という）についても改めて実験を行い, 粘着力のない場合の実験結果を求めた。

実験に用いた砂槽は軽金属板製で，Fig. 2 に示すよう

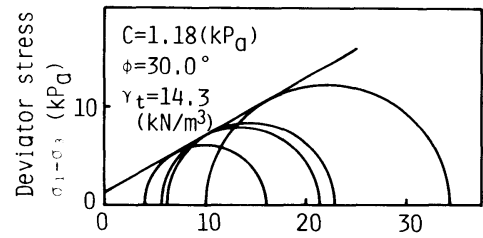

Effective confing pressure $\sigma_{3}\left(\mathrm{KP}_{\mathrm{Q}}\right)$

Fig. 1 Triaxial test result on glycerin sand.

Table 1 Physical properties of sand.

\begin{tabular}{|l|l|}
\hline Specific gravity $\quad G_{S}$ & 2.640 \\
\hline Uni formi ty coefficient $U_{C}$ & 1.58 \\
\hline average grain diameter $D_{50}$ & $0.205 \mathrm{~mm}$ \\
\hline maximum grain diameter $D_{\max }$ & $0.840 \mathrm{~mm}$ \\
\hline
\end{tabular}

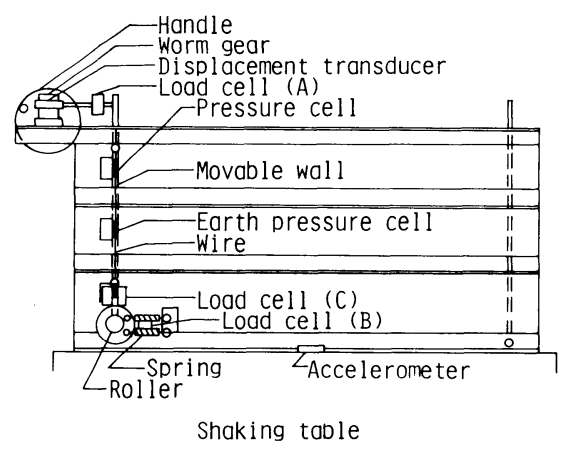

Fig. 2 Shaking sand box.

に, 梁さ, 幅, 長さがそれぞれ $50 \mathrm{~cm} \times 50 \mathrm{~cm} \times 90 \mathrm{~cm}$ で, 振動方向に直角な側壁は，両方とも下端をヒンジとした 可動壁となっている. そしてその1つは，下端のヒンジ が水平および鉛直方向ともロードセルで，上支点も水平 方向にロードセルで支えられており，壁に作用する土圧 合力の水平成分，鉛直成分が測定できるようになってい る.

また，この壁面には，砂層表面からの深さが，それぞ れ $10 \mathrm{~cm}, 25 \mathrm{~cm}, 40 \mathrm{~cm}$ の位置に土圧計が付けられ, 土圧分布も測定できるようになっている。

この側壁は，ハンドルを回転することによって，上支 点をゆっくりと水平方向に変位することができる.

もう 1 つの側壁は上支点が板ばねで支えられていて， 振動中に生じる砂層の変位を極端に拘束しないように, 加わる力に比例して変位する構造になっている。

ロードセルおよび土圧計の出力は, 振動台の加速度, 壁の変位を測る変位計などの出力と一緒にペンオシロに 記録される。

グリセリン砂は， 6 層に分け, タンパー（底面積 14 $\mathrm{cm} \times 20 \mathrm{~cm})$ を用いて, 試料上面を軽く押さえ, 単位重 量ができるだけ均等になるように，砂槽に詰めた。この ようにして用意されたグルセリン砂層の単位重量は $14.3 \mathrm{kN} / \mathrm{m}^{3}$ であった。この值は 3 層目の試料を詰める 際に, 直径 $7.5 \mathrm{~cm}$, 深さ $7.0 \mathrm{~cm}$ の容器 3 個を置いて砂 を詰め, あとで取り出して測定するという方法によった ものである。

乾燥砂は，バケットに入れたものを釣り上げ，ホース を通して砂槽に静かに流し込んで詰めた。単位重量の測 定方法はグリセリン砂と同様であるが，乾燥砂では，深

Table 2 Shearing properties of sands.

\begin{tabular}{|l|c|c|}
\hline & $\begin{array}{c}\text { sand }\left(\gamma_{\mathrm{t}}=\right. \\
\left.13.4 \mathrm{kN} / \mathrm{m}^{3}\right)\end{array}$ & $\begin{array}{c}\text { glycerin sand } \\
\left(\gamma_{\mathrm{t}}=14.3 \mathrm{kN} / \mathrm{m}^{3}\right)\end{array}$ \\
\hline cohesion $\left(\mathrm{KPa}_{\mathrm{a}}\right)$ & 0 & 1.18 \\
\hline $\begin{array}{l}\text { angle of friction } \\
\text { internal friction }\end{array}$ & 37.4 & 31.0 \\
\hline
\end{tabular}


さ $10 \mathrm{~cm}, 25 \mathrm{~cm}, 40 \mathrm{~cm}$ の位置での测定であり，その 平均値は $13.4 \mathrm{kN} / \mathrm{m}^{3}$ であった。

\section{3. 実験方法}

砂槽への砂詰め後, 振動台を水平震度 $k_{h}=0.1$, 振動 数 $3 \mathrm{~Hz}$ で振動する. そして, 振動中に, 可動壁の上支 点（砂表面上 $6.6 \mathrm{~cm}$ の位置）の水平変位が $2 \mathrm{~mm}$ とな るまで壁を $0.01 \mathrm{~mm} / \mathrm{s}$ の速度で, 静かに外側（主働側） に倒す。次に，同じ速度で内側（受働側）へ変位が 4 $\mathrm{mm}$ (はじめの位置からの変位は $2 \mathrm{~mm}$ ) となるまで倒す. さらに，同じ速度で $2 \mathrm{~mm}$ 外側に動かしてはじめの位 置に戻す。

次に, 乾燥砂の場合には, 振動台をいったん止めて振 動中に生じた砂表面の沈下量を測定し, 砂層の単位重量 の変化を求め, 沈下量を補う分だけの砂を補充して詰め, 砂表面を元の高さに戻した。この方法によって求められ た乾燥砂の単位重量は震度 0.4 の振動後, 平均値は $13.8 \mathrm{kN} / \mathrm{m}^{3}$ であった。なお，グリセリン砂では振動中 の沈下はほとんど生じなかったので, 上記の作業は行わ なかった。

このようにして, 順次, 震度 $0.2,0.3,0.4$ として同 様な実験を行った。

上述の動的試験に先立って, 壁を同じように 3 回変位 させて静的試験が行われた。

\section{4. 実験結果とその考察}

Fig. 3, Fig. 4 は静的および動的試験での土圧合力と 壁の上支点の変位の関係, すなわち壁を内および外側に 最大 $2.0 \mathrm{~mm}$ 変位したときの土圧合力の水平成分の変化 を示す.これらはペンオシロの記録の読取值をプロット して作られたものである.なお，この実験では主働土圧

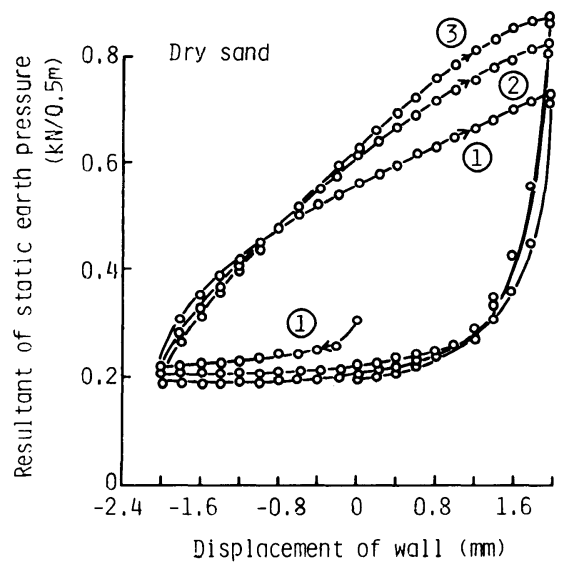

(c)
を求めるのが目的であるので, 動的実験では土圧振幅の 山の值（土圧の最大値）をとった.

これらの図から, 変位サイクル回数が多くなるに従っ て，壁近傍の砂が締まるために，履歴曲線が全く同一に はならないが，静的の場合も，動的の場合もともに主働 側への変位量が $0.8 \mathrm{~mm}$ 以上になると, 土圧合力はほぼ 一定值となり主働状態とみなせる土圧合力が得られてい ると判断される.

そこで, 静的・動的いずれの場合でも主働側への変位 が $2.0 \mathrm{~mm}$ となった点の土圧合力を主働土圧合力と考え て，それらと震度との関係を示したのが，図一5に示す 測定値である.

また，主働土圧合力の壁の上支点と下端のヒンジ点に 作用する水平分力から主働土圧合力の作用高さを求め, 震度との関係を示したのが, Fig. 6 の測定值である.

Fig. 5 から, 乾燥砂, グリセリン砂のいずれの場合も, 主働土圧合力は震度が大きくなるに従って大きくなって おり, 土圧合力は, 乾燥砂の方がグリセリン砂より大き いことがわかる．この土圧合力の差は粘着力によるもの であるが，これは震度によって，ほとんど変化していな いことがFig. 5 からわかる.

このことは, 粘着力によって生じる静的主働土圧合力 の減少量が, 粘着力がある場合とない場合の地震時土圧 合力の差に等しいことを示す.

「道路橋示方書・同解説 V 耐震設計編」には, 地震時 主働土圧の計算式として次式を与えている.

$p_{E a}=\gamma \cdot x \cdot K_{E a}-2 c \cdot \sqrt{K_{E a}}+q^{\prime} \cdot K_{E a}$

ここで,

$p_{E a}:$ 深さ $x$ における地震時主働土圧強度

$K_{E a}:$ 地震時主働土圧係数

$\gamma:$ 土の単位重量

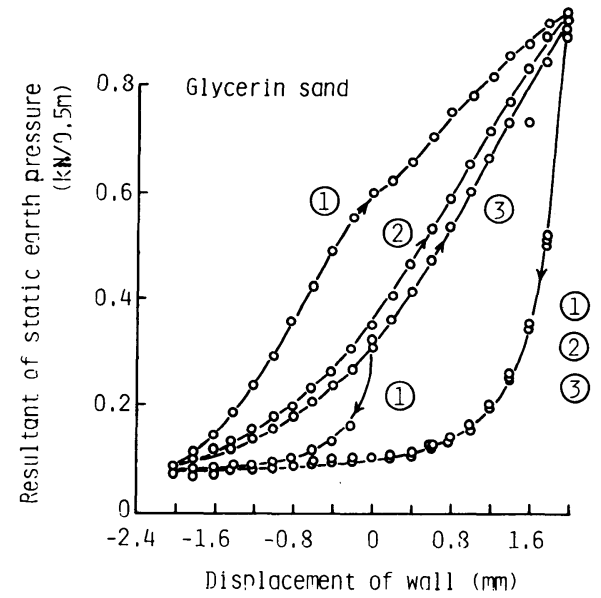

(b)

Fig. 3 Relationships between resultant of static earth pressure and displacement of wall top. 


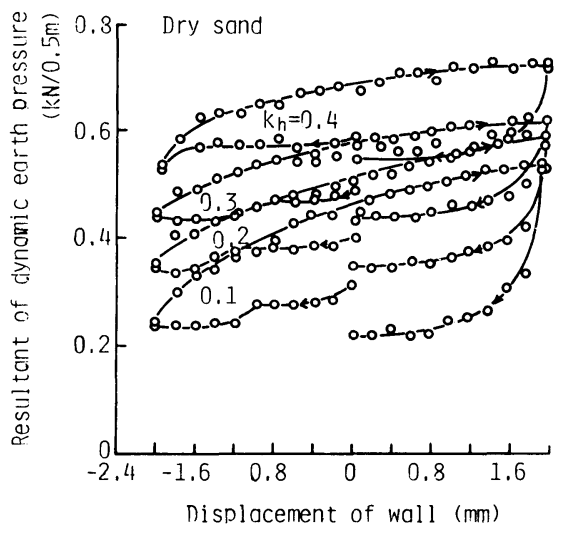

(a)

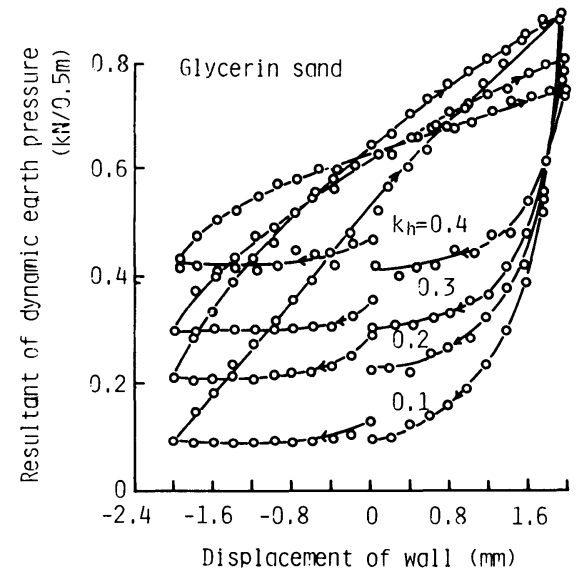

(b)

Fig. 4 Relationships between resultant of dynamic earth pressure and displacement of wall top.

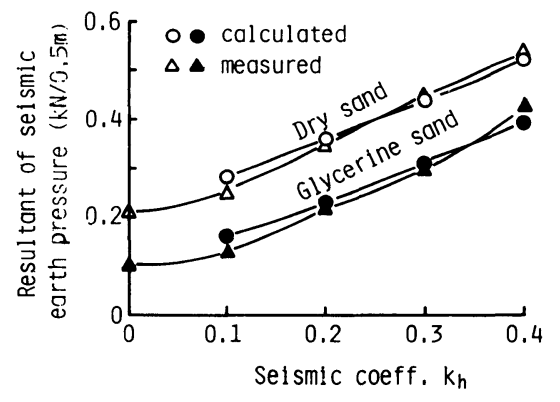

Fig. 5 Resultant of seismic active earth pressure.

\section{$c$ : 土の粘着力}

式（1）の右辺第 2 項が粘着力による主働土圧の減少 量となるが, $\sqrt{K_{E a}}$ は内部摩擦角を $35^{\circ}$ とすると, 震度 0.4 では, 常時 $\left(k_{h}=0\right)$ の 1.45 倍となるので, 式 ( 1$)$ が成り立つならば, 両者の土圧合力值の差は, 震度の増 加とともに大きくならなければならない.

また, 乾燥砂の地震時主働土圧の実験值は通常物部 · 岡部式の計算值より大きく, 両者の差は震度が大きくな るに従って大きくなることが知られている"1. Fig. 5 の 乾燥砂の測定值からもそのことはわかる. すなわち内部 摩擦角が $35^{\circ} \sim 40^{\circ}$ では震度 0.4 のときの $K_{E a}$ の計算値 は常時のそれの約 2 倍となるが, Fig. 5 の土圧合力の測 定値では約 2.5 倍となっている.

この原因は別途検討されている゙が，振動による砂層 の単位重量の増加に伴う内部摩擦角の増加は振動中の内 部摩擦角の減少によって打ち消され, 単位重量の増加の みが地震時土圧の増加を支配するとの考えも成り立つ.

以上の考察から, Fig. 5 に示される両者の土圧合力測 定值の差は式（1）によっては簡単に説明できなかった.

Fig. 7 は, 著者の一人が, 裏込め土を弾性体とみなし

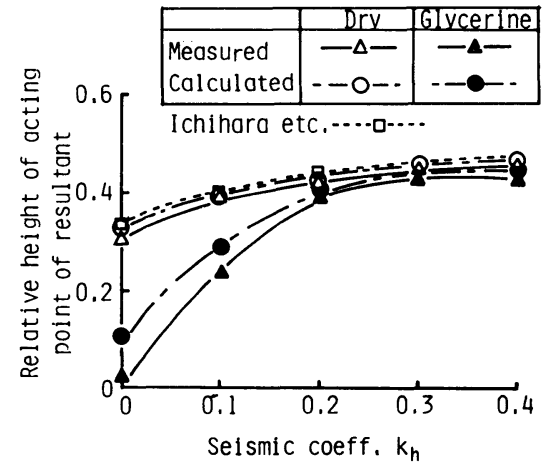

Fig. 6 Relative height of application point of resultant.

て求めた, 地震時土圧の弾性理論解である.この詳細に ついては，すでに多くの発表があるので，ここでは改め て述べない.

この理論解は, Fig.7(b) に示しているように, 砂層 の弾性定数 ( $\lambda, \mu$ : ラメの定数) は深さとともに直線 的に変化するとし, Ritzの近似解および階差法を用い て数值計算したもので, Fig. 7に示す圧力分布は振動土 圧振幅分布である. この理論解を求めるに際して, 著者 は地震時土圧は Fig. 7 に示す振動土圧に静的主働土圧を 加えたものとなると考えた ${ }^{4), 51,9) . ~}$

この考え方に従って, 今回の実験値に相当する地震時 土圧分布の理論解を求めれば, Fig. 8, Fig. 9 に示す分 布が得られる。

Fig. 8 がグリセリン砂, Fig. 9 が乾燥砂の場合である. Fig. 8, Fig. 9 の分布を求めるために用いた, それぞれ の場合の静的主働土王分布は, 土圧計による主働土圧分 布の測定結果を Fig. 3 に示される主働土圧合力で照合し て求められた。図中に，土王計によって測定された地震 


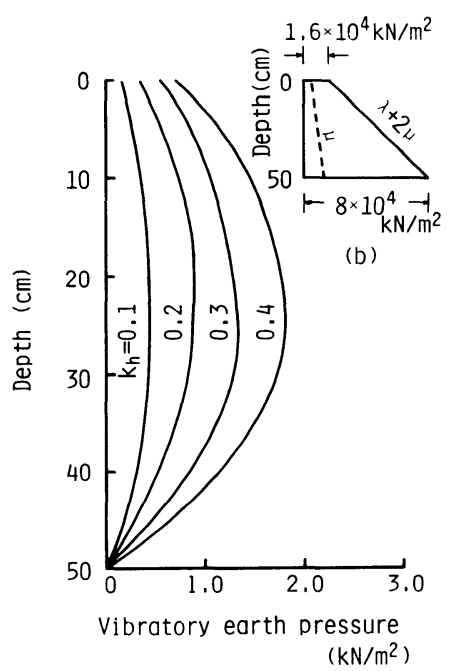

(a)

Fig. 7 Distribution of vibratory earth pressure.

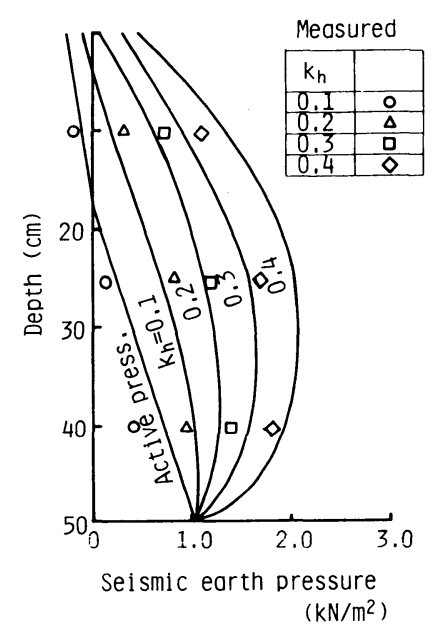

Fig. 9 Distribution of seismic active earth pressure for cohesive sand.

時主㗢土圧值を記入した。測定值は理論分布曲線にほぼ 対応していることがわかる.

Fig. 8, Fig. 9 の地震時主働土圧の理論分布曲線の囲 む面積およびその重心位置を計算する方法で, 土圧合力, 作用高比を求めた結果が Fig. 5, Fig. 6 に示す計算值曲 線である.

合力, 作用高比とも, 計算値は実験値と非常によい一 致を示している.

\section{5. 被災岸壁の考察}

以上述べたように, 粘着力のある砂の実験結果をも含 め, 地震時土圧合力の実験値の考察を行った結果, 先に 発表した振動土圧の理論解を用いることによって, 粘着

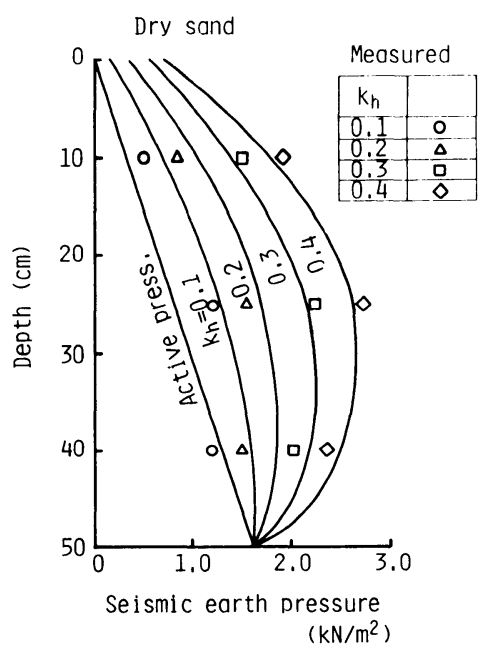

Fig. 8 Distribution of seismic active earth pressure for dry sand.

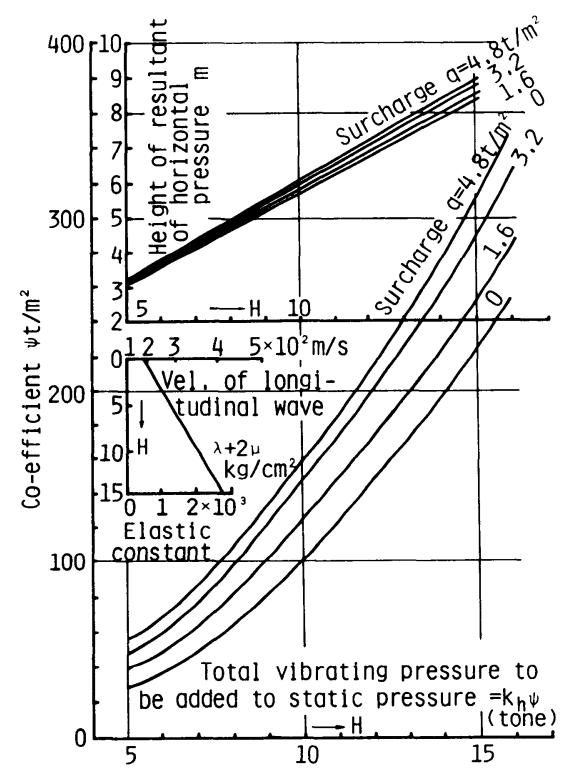

Height of wall $\mathrm{m}$

Fig. 10 Diagram for calculations of vibratory earth pressure and point of application of resultant force.

カのある場合も，ない場合も，その地震時主働土圧の特 性をよりよく説明できることがわかった。

そこで,この振動土圧の理論解を, 実際の岸壁の地震 時土圧の計算に用いた場合の評価を明らかにするため に, 既往の地震によって被災した岸壁などの状況を, こ の理論計算値を用いて考察してみた.

この理論解を用いて, 実際の岸壁に作用する地震時土 圧を計算するために, Fig. 10 に示す計算図表 ${ }^{4) .5}$ が作ら れている. 


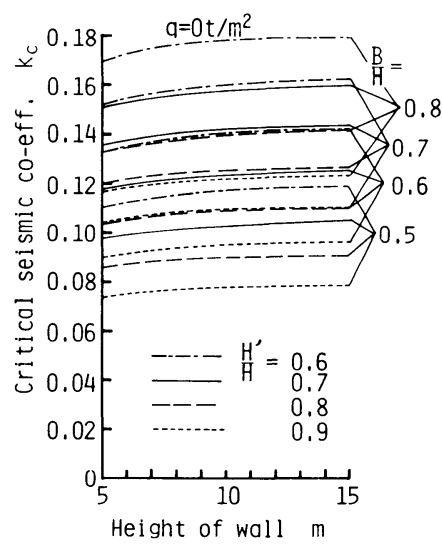

(a)

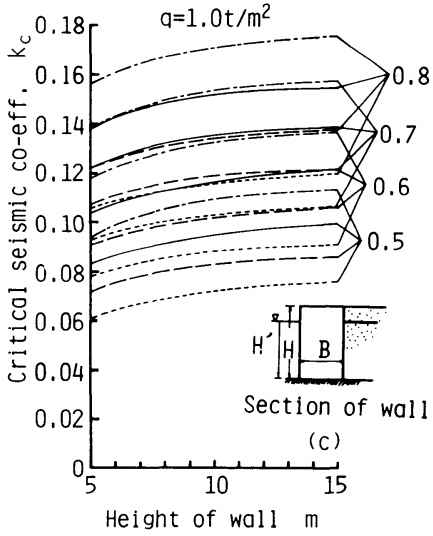

(b)

Fig. 11 Critical seismic coeff. of quay wall for base sliding.

すなわち, Fig. 10 は先に述べた理論解を壁高 $5 \mathrm{~m}$ か ら $15 \mathrm{~m}$ までの岸壁について計算した結果を, 実際の計 算に便利なように，図表としたものである，裏込め土の 弾性定数は図中に示すように，深さとともに直線的に変 化すると考えている．上図が振動土圧合力の作用高さ， 下図が振動土圧合力を求める図表である，下図の縦軸の $\psi$ の值に, 水平震度 $k_{h}$ を乗じ, その震度での振動土圧 合力を求めることができる.

実際の重力式岸壁の震害は底面滑動が最も多いことは 衆知のことである.このことから地震時土圧の計算に Fig. 10 を用い, 壁高: $H$, 壁底幅: $B$, 裏込め残留水深 $: H^{\prime}$ として, 重力式岸壁の地震時の底面滑動限界震度 を求めたのが, Fig. 11 である.

これらの計算式等については前報告 ${ }^{4), 5)}$ に詳しく述べ てあるが, 重要なことなので,ここでもう一度述べる.

Fig. 11 (c) に示すような岸壁を考え, $\gamma$ : 岸壁の空 中単位重量, $K_{a}, K_{a}^{\prime}$ : 裏込め土の主働土圧係数の残留 水位以上と以下の值, $\gamma_{s}, \gamma_{s}^{\prime}$ : 裏込め土の単位重量の残 留水位以上と以下の值, $q$ : 上載荷重, $f$ : 底面摩擦係数,

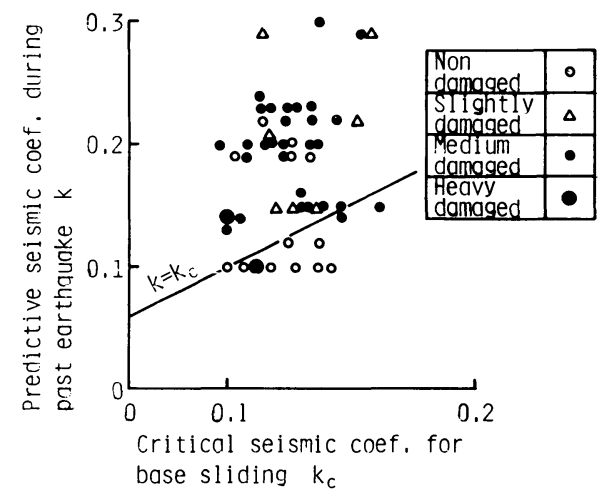

Fig. 12 Examination of stability of damaged quay wall. $k_{h}$ : 水中震度, $\psi$ : 振動土圧値 (Fig. 10 の值), $P_{s}$ : 静 的主㗢土圧合力とし，さらに，壁面摩擦角を $20^{\circ}$, 動水 圧は前面にWestergaard 值，背面にその $70 \%$ の値 ${ }^{5}$ を 考えると，この岸壁に作用する鉛直力の総和は

$$
\gamma B H-B H^{\prime}+0.3 P_{s}
$$

水然平力の総和は, $k_{h} \gamma B H+0.94 P_{s}+k_{h} \psi+1.0 k_{h}$ $H^{\prime 2}$ となる. 水平震度で底面滑動限界の水平震度を $k_{c}$ とおくと，

$$
\begin{aligned}
& f\left(\gamma B H-B H^{\prime}+0.3 P_{s}\right)=0.94 P_{s} \\
& +k_{c} \psi+1.0 k_{c} H^{2}+k_{c} \gamma B H \\
& \text { いま, } f=0.6 \text { とすると } \\
& k_{c}=\left[0.6 \frac{B}{H}\left(\gamma-\frac{H^{\prime}}{H}\right)-0.76 \frac{P_{s}}{H^{2}}\right] \\
& /\left[\frac{\psi}{H^{2}}+1.0 k_{c}\left(\frac{H^{\prime}}{H}\right)^{2}+\gamma \frac{B}{H}\right] \\
& \text { ただし } \\
& \begin{aligned}
\frac{P_{s}}{H^{2}}= & \frac{K_{a}}{2} \gamma_{s}\left(1-\frac{H^{\prime}}{H}\right)^{2}+K_{a}^{\prime} \gamma_{s}\left(\frac{H^{\prime}}{H}-\frac{H^{\prime 2}}{H^{2}}\right) \\
& +\frac{K_{a}^{\prime}}{2} \gamma_{s}^{\prime}\left(\frac{H^{\prime}}{H}\right)^{2}+\frac{q}{H}\left[K_{a}\left(1-\frac{H^{\prime}}{H}\right)+K_{a}^{\prime} \frac{H^{\prime}}{H}\right]
\end{aligned}
\end{aligned}
$$

ここでは, $\gamma=2.0 \mathrm{t} / \mathrm{m}^{3}, K_{a}=0.31, K_{a}^{\prime}=0.25, \quad \gamma_{s}=$ $1.6 \mathrm{t} / \mathrm{m}^{3}, \quad \gamma_{s}^{\prime}=1.0 \mathrm{t} / \mathrm{m}^{3}$ とし, $H, B / H, H^{\prime} / H, q$ な ゼをパラメーターにして, $k_{c}$ が求められた。

次に, 既往の地震によって被災，またはそれに近い状 態となった重力式岸壁 ${ }^{10)}$ の底面滑動限界震度 $k$ 。 を Fig.11 から求め, それとこれらの岸壁が受けたと考 えられる震度 $k$ とを比較した。 $k$ の値には主として港 湾技研資料 No. $\left.227^{10}\right)$ に記載されている作用震度と強震 計で求められた最大加速度を採用した。作用震度は, 上 記文献によれば岸壁法線の沈下・はらみ出し・壁体の傾 斜等の被災状況と滑動・転倒・地盤支持力についての三 
Table 3 Examination of stability of damaged quay walls.

\begin{tabular}{|c|c|c|c|c|c|c|c|c|c|c|}
\hline 地春名 & 港名 & 洋壁種別 & $B$ & H & $\mathrm{B} / \mathrm{H}$ & $\mathrm{H}^{\circ} / \mathrm{H}$ & $\mathrm{kc}$ & $k$ & $\mathrm{kcm}$ & 被害 \\
\hline \multirow[t]{2}{*}{$\begin{array}{l}\text { 闃東 } \\
(1923)\end{array}$} & \multirow[t]{2}{*}{ 棈捠 } & \begin{tabular}{|r|} 
新港埠頭 \\
第1号漳 \\
壁(-6.1m \\
テロック) \\
$(そ の 2)$ \\
\end{tabular} & 4.20 & 7.16 & 0.59 & 0.62 & 0.134 & 0.20 & 0.114 & あり \\
\hline & & $\begin{array}{l}\text { 新䜤埠頍 } \\
\text { 第 } 4 \text { 号岸 } \\
\text { 堅(-9.7m } \\
\text { フロック) }\end{array}$ & 4.30 & 8.79 & 0.49 & 0.64 & 0.116 & 0.20 & 0.096 & $\begin{array}{c}\text { あり } \\
\text { (す } \\
\text { こり } \\
\text { なし }\end{array}$ \\
\hline \multirow[t]{4}{*}{$\begin{array}{l}\text { 北伊豆 } \\
(1930)\end{array}$} & \multirow[t]{4}{*}{ 清水 } & $\begin{array}{c}\text { 日の出埠 } \\
\text { 䫒甲洋壁 } \\
\text { (-i0.17 } \\
\text { ケーソン) }\end{array}$ & 9.6 & 15.0 & 0.64 & 0.84 & 0.118 & 0.10 & 0.098 & なし \\
\hline & & $\begin{array}{l}\text { 日の出淖 } \\
\text { 頡乙岸壁 } \\
\text { (-8.5mケ } \\
\text { ーソン) }\end{array}$ & 7.8 & 12.81 & 0.61 & 0.82 & 0.112 & 0.10 & 0.094 & $\begin{array}{l}\text { 大菠 } \\
\text { 害 }\end{array}$ \\
\hline & & 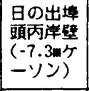 & 7.0 & 10.80 & 0.65 & 0.78 & 0.108 & 0.10 & 0.092 & なし \\
\hline & & 鉄道萍壁 & 7.0 & 11.3 & 0.62 & 0.73 & 0.128 & 0.10 & 0.107 & なし \\
\hline \multirow[t]{4}{*}{$\begin{array}{l}\text { 静网 } \\
(1935)\end{array}$} & \multirow[t]{4}{*}{ 清水 } & $\begin{array}{c}\text { 日の出埠 } \\
\text { 頭甲㴖壁 } \\
(-10.1 \mathbf{m} \\
\text { ケーソン) }\end{array}$ & 9.6 & 14.90 & 0.64 & 0.81 & 0.118 & 0.23 & 0.098 & あり \\
\hline & & 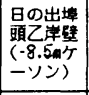 & 7.0 & 10.80 & 0.65 & 0.74 & 0.128 & 0.2 .3 & 0.106 & なし \\
\hline & & $\begin{array}{l}\text { 日の出塻 } \\
\text { 頭丙嵌壁 } \\
(-7.3 \text { ケ } \\
\text { ーソン) } \\
\end{array}$ & 7.0 & 10.80 & 0.65 & 0.69 & 0.134 & 0.23 & 0.112 & あり \\
\hline & & 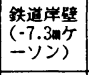 & 7.0 & 11.50 & 0.61 & 0.70 & 0.126 & 0.23 & 0.106 & あり \\
\hline $\begin{array}{l}\text { 男鹿半 } \\
\text { 盛 } \\
\text { (1939) }\end{array}$ & 粉川 & $\begin{array}{l}\text { 洋壁 } \\
\text { ロック } \\
\text { ロック }\end{array}$ & 3.03 & 6.10 & 0.50 & 0.70 & 0.099 & 0.13 & 0.085 & あり \\
\hline \multirow[t]{10}{*}{$\begin{array}{l}\text { 南海 } \\
(1946)\end{array}$} & \multirow[t]{6}{*}{ 宇理 } & $\begin{array}{l}\text { 第1突堤 } \\
2 \text { 号垷 } \\
\text { 先端部 } \\
(-9 \text { フロ } \\
\text { ソクシケ } \\
\text { ーソン) } \\
\end{array}$ & 9.6 & 13.60 & 0.71 & 0.80 & 0.128 & 0.15 & 0.108 & 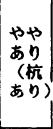 \\
\hline & & $\begin{array}{l}\text { 第 } 1 \text { 突堤 } \\
-5.2 \mathrm{~m} \text { 湈 } \\
\text { 壁 (フロ } \\
\text { ック) } \\
\end{array}$ & 6.51 & 9.60 & 0.68 & 0.73 & 0.137 & 0.15 & 0.117 & $\begin{array}{c}\text { やや } \\
\text { あり } \\
\text { (杭 } \\
\text { あり } \\
\end{array}$ \\
\hline & & 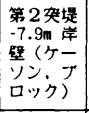 & 8.55 & 13.04 & 0.66 & 0.78 & 0.120 & 0.15 & 0.100 & やや \\
\hline & & $\begin{array}{l}\text { 第2 垁堤 } \\
-5.2 \mathrm{~m} \text { 孛 } \\
\text { 壁(ケー } \\
\text { ソン) }\end{array}$ & 6.5 & 9.85 & 0.66 & 0.71 & 0.135 & 0.15 & 0.114 & あり \\
\hline & & $\begin{array}{l}\text { 第 } 2 \text { 突堤 } \\
2 \text { 号绵頭 }\end{array}$ & 8.55 & 11.8 & 0.72 & 0.67 & 0.146 & 0.15 & 0.123 & \begin{tabular}{|} 
कり \\
(杭 \\
कり) \\
\end{tabular} \\
\hline & & 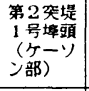 & 6.5 & 9.10 & 0.71 & 0.57 & 0.161 & 0.15 & 0.136 & $\begin{array}{c}\text { あり } \\
\text { (杭 } \\
\text { あり) }\end{array}$ \\
\hline & \multirow[t]{2}{*}{ 坂出 } & 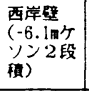 & 5.45 & 10.00 & 0.55 & 0.81 & 0.100 & 0.14 & 0.084 & $\begin{array}{l}\text { 大被 } \\
\text { 害 }\end{array}$ \\
\hline & & 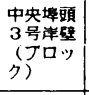 & 7.7 & 13.40 & 0.57 & 0.80 & 0.104 & 0.14 & 0.087 & あり \\
\hline & 血 & 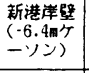 & 7.0 & 10.15 & 0.69 & 0.76 & 0.123 & 0.20 & 0.104 & あり \\
\hline & $\begin{array}{l}\text { 和做 } \\
\text { 山 }\end{array}$ & $\begin{array}{l}\text { かずみ島 } \\
\text { 岸壁 } \\
(-6.4 m フ \\
\text { ック }\end{array}$ & 7.3 & 11.6 & 0.63 & 0.72 & 0.130 & 0.16 & 0.109 & あり \\
\hline
\end{tabular}

\begin{tabular}{|c|c|c|c|c|c|c|c|c|c|c|}
\hline \multirow[t]{5}{*}{ 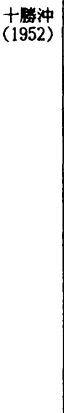 } & \multirow[t]{3}{*}{ 鉦路 } & 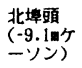 & 8.3 & 12.62 & 0.66 & 0.85 & 0.098 & 0.20 & 0.084 & あり \\
\hline & & 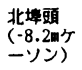 & 7.42 & 11.71 & 0.63 & 0.84 & 0.109 & 0.20 & 0.091 & あり \\
\hline & & $\begin{array}{l}\text { 北垍顥 } \\
(-2.7 \mathrm{~L} \\
\text { 型ブロッ } \\
\text { ク) }\end{array}$ & 3.6 & 5.35 & 0.67 & 0.77 & 0.116 & 0.20 & 0.102 & あり \\
\hline & 浦河 & $\begin{array}{l}\text { 第2物提 } \\
\text { 場(-1.8m } \\
\text { フロック }\end{array}$ & 3.0 & 5.50 & 0.55 & 0.63 & 0.123 & 0.22 & 0.106 & あり \\
\hline & 十 & $\begin{array}{l}\text { 物羁埸 } \\
(-2.4 \text { 七 } \\
\text { ルラーテ } \\
\text { ロック) }\end{array}$ & 3.0 & 5.30 & 0.57 & 0.66 & 0.114 & 0.22 & 0.099 & なし \\
\hline \multirow[t]{4}{*}{$\begin{array}{l}\text { 日向济 } \\
(1961)\end{array}$} & 内海 & $\begin{array}{l}-4.7 \text { 峷 } \\
\text { 䢃)(プロ } \\
\text { ク) }\end{array}$ & 5.1 & 8.90 & 0.57 & 0.66 & 0.117 & 0.20 & 0.099 & $\begin{array}{l}\text { やや } \\
\text { あり }\end{array}$ \\
\hline & \multirow[t]{3}{*}{ 油津 } & 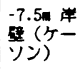 & 6.9 & 8.50 & 0.81 & 0.90 & 0.121 & 0.19 & 0.105 & あり \\
\hline & & $\begin{array}{l}\text {-5.0m } \\
\text { 軗 (フロ } \\
\text { ック) }\end{array}$ & 4.9 & 6.90 & 0.71 & 0.90 & 0.108 & 0.19 & 0.095 & あり \\
\hline & & $\begin{array}{l}-6.6 \text { 崖 } \\
\text { 垶(ケー } \\
\text { ソン) }\end{array}$ & 6.0 & 10.30 & 0.58 & 0.79 & 0.105 & 0.19 & 0.089 & なし \\
\hline \multirow[t]{3}{*}{$\begin{array}{l}\text { 新偲 } \\
(1964)\end{array}$} & 岩粭 & $\begin{array}{l}\text { 物掦埸 } \\
\text { (-3m型 } \\
\text { ブロック }\end{array}$ & 3.4 & 4.9 & 0.69 & 0.70 & 0.134 & 0.20 & 0.118 & あり \\
\hline & 酒田 & 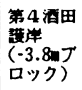 & 2.87 & 4.95 & 0.58 & 0.82 & 0.100 & 0.08 & 0.089 & なし \\
\hline & 秋田 & 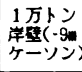 & 9.0 & 11.6 & 0.78 & 0.84 & 0.139 & 0.10 & 0.118 & なし \\
\hline \multirow[t]{11}{*}{ 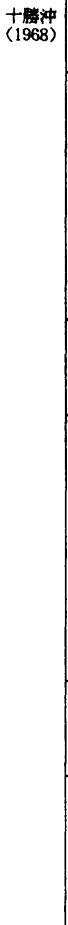 } & 浦河 & $\begin{array}{l}\text { 第3物㧹 } \\
\text { 㙷(型 } \\
\text { デロック) }\end{array}$ & 3.2 & 5.05 & 0.63 & 0.64 & 0.139 & 0.30 & 0.122 & あり \\
\hline & \multirow[t]{3}{*}{ 宮古 } & 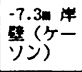 & 7.5 & 10.85 & 0.69 & 0.77 & 0.124 & 0.12 & 0.104 & なし \\
\hline & & $\begin{array}{l}\text { 出䏴地区 } \\
\text {-4物揚 } \\
\text { 埼 (ケー } \\
\text { ソン) }\end{array}$ & 5.0 & 7.1 & 0.70 & 0.68 & 0.139 & 0.12 & 0.120 & なし \\
\hline & & 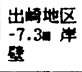 & 7.5 & 10.85 & 0.69 & 0.67 & 0.141 & 0.10 & 0.118 & なし \\
\hline & 画觜 & 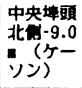 & 8.4 & 12.45 & 0.67 & 0.77 & 0.122 & 0.20 & 0.102 & なし \\
\hline & \multirow[t]{3}{*}{ 室言 } & 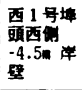 & 5.0 & 7.5 & 0.67 & 0.60 & 0.152 & 0.22 & 0.130 & $\begin{array}{l}\text { やや } \\
\text { あり }\end{array}$ \\
\hline & & 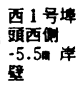 & 5.7 & 8.5 & 0.67 & 0.65 & 0.135 & 0.22 & 0.116 & あり \\
\hline & & $\begin{array}{l}\text { 西2号墇 } \\
\text { 畐-7.5 } \\
\text { 学壁 }\end{array}$ & 7.5 & 10.50 & 0.71 & 0.71 & 0.144 & 0.22 & 0.122 & あり \\
\hline & 青森 & $\begin{array}{l}\text { 浜町嬶頭 } \\
-5.5 \text { 等 } \\
\text { 壁(ケー } \\
\text { ソン) }\end{array}$ & 4.5 & 8.0 & 0.56 & 0.69 & 0.114 & 0.24 & 0.107 & あり \\
\hline & \multirow[t]{2}{*}{ 八戸 } & $\begin{array}{l}\text { 乘地区 } \\
-5.0 \text { 岸 } \\
\text { 壁 }\end{array}$ & 4.5 & 7.5 & 0.60 & 0.67 & 0.122 & 0.19 & 0.104 & なし \\
\hline & & $\begin{array}{l}\text { 白銀嬶頭 } \\
-9.0 \text { 等 } \\
\text { 壁 }\end{array}$ & 9.0 & 12.0 & 0.75 & 0.75 & 0.133 & 0.19 & 0.113 & なし \\
\hline \multirow[t]{2}{*}{$\begin{array}{l}\text { 根室半 } \\
\text { 舁沖 } \\
\text { (1973) }\end{array}$} & 厚崖 & $\begin{array}{c}\text {-4n 学壁 } \\
\text { (L型J } \\
\text { ロック) }\end{array}$ & 4.8 & 6.3 & 0.76 & 0.71 & 0.147 & 0.14 & 0.129 & あり \\
\hline & 花咲 & $\begin{array}{l}-5.5 \text { 岸 } \\
\text { 㹂( (L型 } \\
\text { フロック) }\end{array}$ & 6.3 & 7.9 & 0.80 & 0.70 & 0.156 & 0.29 & 0.135 & あり \\
\hline
\end{tabular}




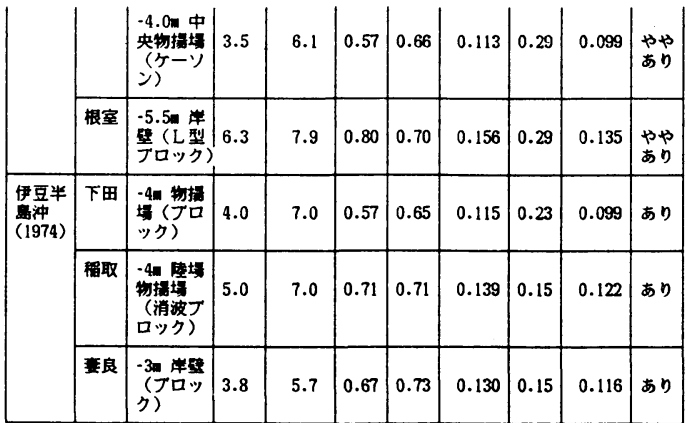

種の安定計算で求められた震度から判定された值であ る. 強震計による最大加速度は新潟地震以降は記載され ているので，その分についてはこれを採用した。

なお，これらの值は震度階分布図 ${ }^{11)} と の$ 対応によって 照合した。

また， $k$ の值はそれぞれの岸壁について異なった値を 用いず，同じ地震の同じ港では同一とした。

Table 3 がその結果である. 被災岸壁のほとんどにお いて，kが $k_{c}$ を上回っていて，被災を裏付けている. しかし, この中には, 北伊豆地震の清水港甲および丙岸 壁や十勝沖地震の宮古港の $-7.3 \mathrm{~m}$ 岸壁のように $k_{c}>k$ となって, 被害がほとんどなかったことが裏付けられ た岸壁もあるが，そうでないものもある.

結局, Table 3 に揭げた 51 の岸壁のうち, 被害があっ たのが 33，なかったのが14で，被災が裏付けられたの が 31 ，無被害が裏付けられたのが 8 であった。

この結果を Fig. 12 にも示した.

ここで採用した $k$ の値および Table 3 に揭げた重力 式岸壁の被害が地震時土圧によるものかどうか等につい ては検討の余地があるが, 被害が地盤の液状化によるこ とが明らかである新潟地震の際の新潟港の岸壁は除外 し、ここに揭げた岸壁の被害は底面滑動が主であること から，地震時土圧による被害と考えて検討を試みた。

また, Table 3 の $k_{c m}$ は, 地震時土圧の計算に物部・岡 部式を用いて求められた底面滑動限界震度である. $k_{c m}$ は $k_{c}$ より小さくなり， $k_{c m}$ を用いて被災岸壁の裏付け 調査を行った場合は， $k_{c}$ による調査では裏付けられた 北伊豆地震の清水港甲岸壁をはじめ 4 つの岸壁の無被害 が裏付けられなくなる。 その結果, 無被害の岸壁 14 の うち，それが裏付けられたのは 4 とやや少なくなる.

\section{6. 結 語}

地震時土圧に対する粘着力の影響を明らかにするため に, 深さ $50 \mathrm{~cm}$, 幅 $50 \mathrm{~cm}$, 長さ $98 \mathrm{~cm}$ の砂槽を振動台 上におき，わずかの粘着力をもたせるために，グリセり ンを混合した豊浦砂を詰めて実験を行った。
実験に用いた砂槽の壁は下端がヒンジとなっており， 上支点を変位することによって，わずかに回転する．そ して，下端ヒンジは上下および水平方向に，上支点も水 平方向にロードセルで支えられており，壁に加わる土圧 合力およびその作用高さが求められる．また，壁面には 3 個の土圧計が取り付けてあって，土圧分布も測定でき るようになっている.

実験では，壁は静止時と振動中に内側および外側に変 位され, 壁の変位と土圧合力, 土圧分布との関係がわか り, 地震時主働土圧合力, その作用高および分布が求め られ，検討された。

土圧合力の測定値において，乾燥砂とグリセリン砂の 地震時主働土圧合力の差が震度によって変化せず，静的 主働土圧合力の差に等しいという結果に注目して考察を 行った.

すなわち, 地震時土圧は静的土圧と振動土圧から成り， 後者は粘着力には無関係で, 震度のみに比例して大きく なると考えれば，地震時主働土圧は，静的主働土圧と振 動土圧の和として求められ，上述の実験結果を説明でき ることになる.

振動土圧としては, 著者の一人が先に発表した計算値 を用い，実験で求められた土圧合力，作用高および土圧 分布と一致する地震時主働土圧の計算值を得ることがで きた.

そこで，この地震時主働土圧の計算法および計算値を 実際の岸壁の設計に用いた場合の評価を明らかにするた めに, この地震時主働土圧計算法を適用した場合の岸壁 の底面滑動限界震度を計算し, 既往の地震による岸壁の 被害との対応を試みた。

その結果，ここで取り上げた岸壁の $80 \%$ について， よい対応が得られた。

おわりに, 実験を手伝った学生, 米原 勝君（現, 島 根県）と計算および論文作製を手伝った黒田早苗娂に謝 意を表します．また，実験には，昭和 58 年度科学研究 費を支出したことを付記する.

\section{参考文献}

1）大原資生：地震時土圧研究の現況亡課題, 土木学会誌, pp. 2 8, 1979.

2）日本道路協会：道路橋示方書・同解説 $\mathrm{V}$ 柇震設計論, pp. 10 12, 1970.

3）市原松平・山田公夫・暒井源一朗：裏込め土が内部摩擦 角をもつ粘性土の地震時主働土圧の算定, 土木学会論文 報告集，第 302 号, pp. 89 101，1980.

4）松尾春雄・大原資生：重力式岸壁の耐震性についての一 考察, 土木学会論文集, 第 70 号, pp. 1 7, 1960.

5) Matuo, H. and Ōhara, S. : Lateral Earth Pressure and Stability of Quay Walls During Earth-Quakes, Proc. of 2nd WCEE, pp. 165 181, 1960.

6）大原資生・前原 博・永田洋文：地震時主働土圧につい 
て, 土と基礎, 18 巻 2 号, pp. 27 35, 1970.

7) Matuo, H. and Ōhara, S. : Dynamic Pore Water Pressure Acting on Quay Walls During Earth-Quakes, Proc. of 3nd WCEE, Vol.1, pp. 1 11, 1965.

8）大原資生・山本哲朗：粘着力をもつ土の地震時主働土圧 に関する研究, 土と基礎, 30 巻 4 号, pp. 33〜 37, 1982.

9) Seed, H. B. and Whitmanm, R. V. : Design of Earth Retaining Structures for Dynamic Loads, conf. on
Lateral Stresses and Earth-Retaining Structures, ASCE, pp.3 147, 1970.

10）野田節男 ·上部達生 : 重力式岸壁の地震被災例集, 港湾 技研資料, No. 227, 1975 .

11）宇佐美竜夫：日本被害地震総覧, 東京大学出版会, 1975 .

12）松尾春雄 : 清水港岸壁の復旧並に補強工事に就て, 土木 学会誌, 23 巻 9 号, pp. 1 15, 1937.

(1984.8.6 • 受付) 